\title{
Effect of Using Garlic on the Economical and Physiological Characteristics of Broiler Chickens
}

\author{
Motasem AL Massad ${ }^{1}$, D AL Ramamneh ${ }^{2}$, Ali AL Sharafat ${ }^{3 *}$ and N Hussain ${ }^{4}$ \\ ${ }^{1}$ Department of Animal Production and Protection, Jerash University, Jordan \\ ${ }^{2}$ Department of Biology, Tabuk University, Kingdom of Saudi Arabia \\ ${ }^{3}$ Department of Agricultural Economics and Extension, Jerash University, Jordan \\ ${ }^{4}$ Livestock and Rangeland Directorate, National Centre for Agricultural Research and Extension, Jordan
}

Submission: April 10, 2018; Published: April 23, 2018

*Corresponding author: Ali Alsharafat, Department of Agricultural Economics and Extension, Faculty of Agriculture, Jerash University, P. 0. Box 311, Postal Code26150, Jerash-Jordan, E-mail: alijerash@gmail.com

\begin{abstract}
The aim of this investigation was to evaluate the beneficial effects of garlic powder as a phytogenic supplement on broilers chickens performance. The assumption that garlic could improve some economic and performance characteristics of broiler chickens (i.e. body weight, feed intake, water intake, feed conversion ratio, feeding cost, carcass yield and mortality rate) was tested. A total of 400 one-day-old chicks of mixed sex (Hybrid) were weighed and randomly assigned to four treatment groups, each with 4 replicate pens of 25 chicks. The dietary treatments included the basal diet (control), control $+2.5 \mathrm{~kg} /$ ton Garlic, or control $+5 \mathrm{~kg} /$ ton Garlic or $7.5 \mathrm{~kg} / \mathrm{ton}$ Garlic as powder. The results of the study revealed that incorporation of garlic powder in broiler diets as feed additive significantly enhanced growth, economic and productive performance of these chickens. Physiological measurements (body weight, weight gains, feed intake, feed conversion ratio, carcass weight and internal organs) showed better performance of garlic treated chickens compared with control group under same rearing system. The results similarly showed lower susceptibility to diseases and medicament treatment consequently; lower mortality rate compared to control groups. Furthermore, blood and meat analysis showed lower cholesterol, Triglyceride, LDL, and, HDL levels compared with control group. The study concluded that Garlic can be effectively used in broilers feeding to replace antibiotic as growth promoter.
\end{abstract}

Keywords: Garlic powder; Phytogenic supplement; Broilers chickens; Economical characteristics; Physiological Characteristics

\section{Introduction}

Feed additives have been widely used in poultry nutrition as a tool of increasing animal productivity [1], improving performance and, health of broiler chickens [2]. Most of the plant parts contain compounds with proven antibacterial, antiviral, antiparasitic, antifungal properties and has antihypertensive, hypoglycemic, antithrombotic, antihyperlipidemic, and antiinflammatory and antioxidant activity. Garlic (Allium Sativum) has been found that lower serum and liver cholesterol [3], inhibit bacterial growth [4], inhibit platelet growth and reduce oxidative stress. In pursuit of improved chicken healthiness and in order to fulfill consumer expectations in relation to food quality, poultry producers more and more commonly apply natural feeding supplements, mainly herbs [5].

Feed additives are generally used to improve feed intake and, increase growth rate in broilers [6]. Garlic is a perennial herb with a bulb divided into cloves [7] and belongs to the family Amaryllidaceous and genus Alliums. Garlic has several beneficial effects on both humans and animals having antimicrobial, antioxidant as well as antihypertensive properties [8]. It is widely used in all parts of world as a spice and herbal medicine for prevention and treatment of a variety of diseases ranging from infection to heart diseases. Garlic has several beneficial effects on both humans and animal having antimicrobial, antioxidant properties [9]; antiviral [10]; and antifungal [11]. Garlic is considered as a plant with antibiotic, anticancer, antioxidant, immunomodulatory, anti-inflammatory, hypoglycemic and cardiovascular- protecting effects. Garlic supplement to broiler feeds has been recognized for its strong stimulating effect on the immune system in addition to its positive effects on digestion in birds due to the very rich aromatic essential content of it [12].

These functions were attributed to the bioactive compounds present in garlic such as alliin, dailylsulphide and allicin [13], which possess antimicrobial activity [14] that could be responsible for the growth promoting effect of garlic. [15] Reported that the best performance was gotten by group of birds fed on diet containing 3\% garlic powder and they got the highest feed consumption. Garlic supplementation at $0.25 \%$ in broiler finisher diets enhanced the feed conversion ratio and hence 
growth rate of the birds and the best performance was attained by the group of birds fed on diet containing $3 \%$ garlic powder had best feed conversion efficiency [16]. Tollba and Hassan [17] reported that garlic improved broiler growth, feed conversion ratio (FCR) and decreased mortality rate. Onibi et al. [18] reported that powdered garlic at $0.5 \%$ might be incorporated as a growth promoter in the ration of Japanese quails. To the authors knowledge this is the first study carried out to investigate the effect of using garlic in basal diet of broilers on the overall performance, reduce spread of diseases and parasites in poultry cycles.

Therefore, we aimed to examine the effect of adding garlic powder in broiler diet on its productivity and physiological characteristics (i.e. body weight, feed intake, water intake, feed conversion ratio, feeding cost, carcass yield and mortality rate).The results from this experiment will be used for further research studies in layers and other animal species (Turkey or sheep and goats...etc.).

\section{Materials and Methods}

The experiment was conducted at Livestock Field Research Station; Department of Animal Production, Faculty of Agriculture, at Jerash University/ Jordan.

\section{Animals and dietary treatments}

Fourteen hundred one-day-old chicks of mixed sex (Hybrid) were weighed and randomly assigned to each of the four treatment groups, each with 4 replicate pens of 25 chicks. The dietary treatments included the basal diet (control), control $+2.5 \mathrm{~kg} /$ ton garlic, or control $+5 \mathrm{~kg} /$ ton garlic or $7.5 \mathrm{~kg} /$ ton garlic as powder. Basal diet was formulated according to nutrient requirements of broilers provided by National Research Council [19]. Birds were fed a starter diet from day 0 to 21 and grower diet from day 22 to 42 . All the dietary treatments were added to the basal diets. Chicks were raised on floor pens $(120$ $\mathrm{cm} \times 120 \mathrm{~cm} \times 80 \mathrm{~cm}$ ) for 6 weeks and had free access to feed and water throughout the entire experimental period. The lighting program consisted of a period of $23 \mathrm{~h}$ light and $1 \mathrm{~h}$ of darkness. The ambient temperature in experimental house was maintained at $32{ }^{\circ} \mathrm{C}$ during the first week and gradually decreased by $3{ }^{\circ} \mathrm{C}$ in the second and third weeks, and finally fixed at $22^{\circ} \mathrm{C}$ thereafter. Results
Both groups either control or treatment groups were vaccinated according to vaccination schedule that are used in Jordanian farming under normal rearing system according to the following vaccination program. (d1 and 7: Infectious Bronchi and New Castle, d 14:Gumboro; d 21: New Castle vaccine). During the experimental period no medicaments were offered to the chickens groups either controlled or treated with garlic.

\section{Performance and carcass components}

Body weights of birds were determined every week. Feed intake and weight gain were recorded during a $7 \mathrm{~d}$ period on a per cage basis and feed conversion ratio (FCR) was calculated. Mortality was recorded as it occurred and was used to adjust the total number of birds to determine the total feed intake per bird and FCR. At $42 \mathrm{~d}$ of age, two birds per replicate were randomly chosen, based on the average weight of the group and slaughtered through cutting carotid arteries. Carcasses weights, dressing percentages, carcass cuts that included: wings, back, breast and legs, abdominal fat were weighed. Internal organs (Crop, proventriculus, gizzard, liver, heart, and small intestine) were weighed separately. The length of small intestine and the weight were record. Meat samples from (Breast, leg, liver) after boneless, were separately ground in a meat grinder and samples from each part were used for dry matter, protein and fat determination.

Cecal microbial count and populations, mortality rate, meat sensory quality test, and intestinal lesion scoring were measured also with veterinary specialist. Blood samples were collected after slaughtering of the chickens into heparinized tubes from 8 chicks within treatments deprived of feed for 24 hours at the end of experiment ( $42 \mathrm{~d}$ ). Serum were obtained by centrifuge blood at 4000 round per minute for 10 minutes to evaluate $\mathrm{s}$ cholesterol, triglycerides, HDL, LDL, total protein, and albumin.

\section{Statistical Analysis}

Data from the randomized design were subjected to an analysis of variance using the MIXED model procedure of SAS. An ANOVA with repeated measures were used. The mean differences among different treatments were separated by Turkey-Kramer test. A level of $(\mathrm{P}<0.05)$ was used as the criterion for statistical significance.

Table 1: Average body weight (gram / bird) when supplementary powder garlic (0,2.5, 5 , and $7.5 \mathrm{~kg} /$ ton) added to the ration per week.

\begin{tabular}{|c|c|c|c|c|}
\hline \multirow{2}{*}{ Age / Week } & \multicolumn{4}{|c|}{ Dietary Treatment $(\mathrm{kg} /$ ton $)$} \\
\cline { 2 - 5 } & 0 & 2.5 & 5 & 7.5 \\
\hline First & $162.8 \pm 0.7^{\mathrm{a}}$ & $164.3 \pm 0.7^{\mathrm{a}}$ & $167.3 \pm 0.7^{\mathrm{a}}$ & $370.3^{\mathrm{a}} \pm 0.7^{\mathrm{a}}$ \\
\hline Second & $374.9 \pm 0.7^{\text {a }}$ & $352.2 \pm 0.7^{\text {be }}$ & $379.4 \pm 0.7^{\text {bc }}$ & $723.3 \pm 0.7^{\text {bd }}$ \\
\hline Third & $690.5 \pm 0.7^{\text {a }}$ & $690.1 \pm 0.7^{\text {ae }}$ & $758.9 \pm 0.7^{\text {bc }}$ & $1181.0 \pm 0.7^{\text {bd }}$ \\
\hline Fourth & $1120.8 \pm 0.7^{\text {a }}$ & $1140.1 \pm 0.7^{\text {be }}$ & $1217.9 \pm 0.7^{\text {bc }}$ & $1549.4 \pm 0.7^{\text {ae }}$ \\
\hline Fifth & $1549.7 \pm 0.7^{\text {a }}$ & $1582.1 \pm 0.7^{\text {bd }}$ & $1653.5 \pm 0.7^{\text {bc }}$ & $2213.8 \pm 0.7^{\text {bd }}$ \\
\hline Sixth & $2053.7 \pm 0.7^{\text {a }}$ & $2115.7 \pm 0.7^{\text {be }}$ & $2277.7 \pm 0.7^{\text {bc }}$ & \\
\hline
\end{tabular}


Results showed that garlic powder improved bird's body weight. The body weight increases significantly every week with higher rates when garlic powder offered at $5 \mathrm{~kg} /$ ton level. Furthermore, using garlic showed earlier effect on body weight at the second week of age (Table 1). The internal organs including the digestive tract and other inedible parts, which form a large part of the weight further, have heavier weight when garlic were offered compared to control group. Carcass weight showed better characteristic of treated chicken with garlic compared

Table 2: Average feed intake (gram / bird), feed conversion ration when supplementary powder garlic $(0,2.5,5$, and $7.5 \mathrm{~kg} /$ ton) added to the ration per week.

\begin{tabular}{|c|c|c|c|c|}
\hline \multirow{2}{*}{ Age $/$ Week } & \multicolumn{4}{|c|}{ Dietary Treatment $(\mathrm{kg} / \mathrm{ton})$} \\
\cline { 2 - 5 } & 0 & 2.5 & 5 & 7.5 \\
\hline First & $137.0 \pm 1.2 \mathrm{a}$ & $138.8 \pm 1.2 \mathrm{a}$ & $147.5 \pm 1.2 \mathrm{a}$ & $138.3 \pm 1.2 \mathrm{a}$ \\
\hline Second & $266.5 \pm 1.2 \mathrm{a}$ & $267.5 \pm 1.2 \mathrm{ac}$ & $260.8 \pm 1.2 \mathrm{ad}$ & $268.8 \pm 1.2 \mathrm{ac}$ \\
\hline Third & $524.0 \pm 1.2 \mathrm{a}$ & $516.3 \pm 1.2 \mathrm{be}$ & $547.0 \pm 1.2 \mathrm{bc}$ & $525.3 \pm 1.2 \mathrm{ad}$ \\
\hline Fourth & $805.8 \pm 1.2 \mathrm{a}$ & $802.8 \pm 1.2 \mathrm{ad}$ & $803.8 \pm 1.2 \mathrm{ad}$ & $827.3 \pm 1.2 \mathrm{bc}$ \\
\hline Fifth & $881.8 \pm 1.2 \mathrm{a}$ & $849.3 \pm 1.2 \mathrm{bc}$ & $821.3 \pm 1.2 \mathrm{be}$ & $834.5 \pm 1.2 \mathrm{bd}$ \\
\hline Sixth & $1082.8 \pm 1.2 \mathrm{a}$ & $1078.8 \pm 1.2 \mathrm{ae}$ & $1223.0 \pm 1.2 \mathrm{bc}$ & $1180.5 \pm 1.2 \mathrm{bd}$ \\
\hline FCR & $1.23 \pm 0.43 \mathrm{a}$ & $1.25 \pm 0.49 \mathrm{a}$ & $1.22 \pm 0.49 \mathrm{a}$ & $1.23 \pm 0.47 \mathrm{a}$ \\
\hline
\end{tabular}

Table 3: Average live, carcass weight (gram / bird) and dressing percent when supplementary garlic powder $(0,2.5,5$, and $7.5 \mathrm{~kg} /$ ton $)$ added to the ration.

\begin{tabular}{|c|c|c|c|c|}
\hline \multirow{2}{*}{ Variable (gram) } & \multicolumn{4}{|c|}{ Dietary Treatment (kg / ton) } \\
\hline & $\mathbf{0}$ & 2.5 & 5 & 7.5 \\
\hline Live weight & $2053.8 \pm 3.5^{\mathrm{a}}$ & $2115.8 \pm 3.9^{\text {be }}$ & $2277.8 \pm 3.9^{\mathrm{bc}}$ & $2213.6 \pm 3.0^{\text {bd }}$ \\
\hline Carcass weight & $1503.3 \pm 2.6^{\mathrm{a}}$ & $1575.3 \pm 2.6$ be & $1715.3 \pm 3.6^{\mathrm{bc}}$ & $1655.8 \pm 3.4^{\text {bd }}$ \\
\hline Chest weight & $523.9 \pm 0.9^{a}$ & $562.4 \pm 0.9$ be & $632.1 \pm 1.3^{\mathrm{bc}}$ & $595.7 \pm 1.2^{\text {bd }}$ \\
\hline Thigh weight & $485.5 \pm 0.8^{a}$ & $496.2 \pm 0.8^{\text {be }}$ & $514.1 \pm 1.1^{\mathrm{bc}}$ & $510.0 \pm 1.0^{\text {bd }}$ \\
\hline Back weight & $202.9 \pm 0.4^{\text {a }}$ & $217.4 \pm 0.4$ be & $224.7 \pm 0.5^{\mathrm{bc}}$ & $218.6 \pm 0.4^{\text {bd }}$ \\
\hline Wings weight & $163.4 \pm 0.3^{\text {a }}$ & $175.5 \pm 0.3$ be & $199.0 \pm 0.4^{\mathrm{bc}}$ & $187.1 \pm 0.4^{\text {bd }}$ \\
\hline Neck weight & $85.8 \pm 0.2^{a}$ & $93.4 \pm 0.2$ be & $99.6 \pm 0.2^{\text {bd }}$ & $101.3 \pm 0.1^{\mathrm{bc}}$ \\
\hline Abdominal fat weight & $124.8 \pm 0.2^{\mathrm{a}}$ & $41.4 \pm 0.1^{\mathrm{bc}}$ & $37.4 \pm 0.1$ be & $43.1 \pm 0.1^{\text {bd }}$ \\
\hline Digestive tract weight & $173.9 \pm 0.3^{\text {a }}$ & $166.5 \pm 0.3$ be & $168.4 \pm 0.4^{\text {bd }}$ & $176.7 \pm 0.4^{\mathrm{bc}}$ \\
\hline Crop weight & $8.4 \pm 0.1^{\mathrm{a}}$ & $7.4 \pm 0.1^{\text {bd }}$ & $6.7 \pm 0.1$ be & $8.1 \pm 0.1^{\text {ac }}$ \\
\hline Proventriculus weight & $8.3 \pm 0.1^{\text {a }}$ & $8.0 \pm 0.1$ ad & $8.4 \pm 0.1^{\text {ad }}$ & $9.3 \pm 0.1^{\mathrm{bc}}$ \\
\hline Gizzard weight & $47.8 \pm 0.1^{\mathrm{a}}$ & $54.2 \pm 0.1^{\mathrm{bc}}$ & $40.5 \pm 0.1$ be & $47.7 \pm 0.1^{\text {ad }}$ \\
\hline Small intestine weight & $63.3 \pm 0.1^{\text {a }}$ & $67.7 \pm 0.1^{\mathrm{bc}}$ & $54.4 \pm 0.1^{\text {bd }}$ & $69.2 \pm 0.1^{\mathrm{bc}}$ \\
\hline Liver weight & $47.8 \pm 0.1^{\text {a }}$ & $54.2 \pm 0.1^{\mathrm{bc}}$ & $40.5 \pm 0.1$ be & $47.7 \pm 0.1^{\text {bd }}$ \\
\hline Heart weight & $13.8 \pm 0.1+$ & $11.0 \pm 0.1^{\mathrm{bc}}$ & $10.3 \pm 0.1^{\text {bd }}$ & $11.6 \pm 0.1^{\mathrm{bc}}$ \\
\hline
\end{tabular}

Using garlic powder promote small intestine length in compare with control groups and depressed in lesion scores of small intestine and lowering the coccidian eggs account when garlic powder is added to the ration (Table 4). Using garlic in broiler diet reduced the blood cholesterol, Albumin, Triglyceride, and HDL as compared to the standard levels. As shown in the table above, chicken those have garlic in their feeding are with lower cholesterol, Triglyceride, LDL, HDL levels compared with control groups (Table 5). with the control group under same rearing system. Feed intake significantly $(\mathrm{P}<0.05)$ tended to be higher in the birds that fed on garlic powder diets compared to the control group under same rearing system (Table 2). Increasing body weight resulted in increasing carcass and eviscerated yields at $5 \mathrm{~kg} /$ ton of used garlic powder (Table 3). In addition, using garlic powder resulted in increased body weight changes and improved feed conversion ratio compared with control group birds. 
with $3 \%$ garlic powder had significantly $(\mathrm{P}<0.05)$ heaviest body weight gain, highest feed intake, best feed conversion ratio with highest dressing and breast percentages. Improved feed intake was noticed in chicks fed with garlic powder compared with

Table 4: Average small intestine long $(\mathrm{cm})$ when supplementary powder garlic $(0,2.5,5$, and $7.5 \mathrm{~kg} /$ ton) were added to the ration.

\begin{tabular}{|c|c|c|c|c|}
\hline \multirow{2}{*}{ Age / Week } & \multicolumn{4}{|c|}{ Dietary Treatment $(\mathrm{kg} /$ ton $)$} \\
\cline { 2 - 5 } & 0 & 2.5 & 5 & 7.5 \\
\hline Small intestine long $(\mathrm{cm})$ & $201.0 \pm 1.8^{\mathrm{a}}$ & $203.0 \pm 1.8^{\text {ae }}$ & $237.0 \pm 2.2^{\mathrm{bc}}$ & $230.0 \pm 1.4^{\mathrm{bd}}$ \\
\hline Small Intestine lesion score $(\mathrm{n})$ & $11.0 \pm 3.3^{\mathrm{a}}$ & $11.3 \pm 2.1^{\mathrm{ac}}$ & $7.8 \pm 4.2^{\text {ad }}$ & $9.0 \pm 2.4^{\mathrm{bd}}$ \\
\hline Coccidia eggs account $\left(\mathrm{n} X 10^{4}\right)$ & $4.5 \pm 2.1^{\mathrm{a}}$ & $4.0 \pm 1.8^{\mathrm{ac}}$ & $3.5 \pm 1.7^{\mathrm{bcd}}$ & $3.3 \pm 1.7^{\mathrm{ac}}$ \\
\hline
\end{tabular}

Similar results obtained by Elagib et al. [15] who reported that the best performance was attained by the group of birds fed on diet containing $3 \%$ garlic as a powder. Furthermore, Racesi et al. [21] indicated that, diet supplemented with garlic powder at level 1-3\% had significantly feed intake compared to the control diet without garlic. Using garlic powder improved feed conversion ratio in this investigation that can be attributed to allicin active ingredients in garlic that promotes the performance of intestinal

flora, thereby improving digestion and enhance the utilization of energy. In addition, the better-feed conversion ratio can be attributed to the antibacterial properties of the garlic powder, which resulted in better absorption of the nutrients in the gut and finally leading to improvement in feed conversion ratio. Tollba and Hassan [17] reported that added garlic to broiler ration improved broiler growth and feed conversion ratio (FCR) and decreased mortality rate.

Table 5: Average blood cholesterol, Albumin, Triglyceride and HDL levels when supplementary garlic powder $(0,2.5,5$, and $7.5 \mathrm{~kg} /$ ton $)$ were added to the ration.

\begin{tabular}{|c|c|c|c|c|c|}
\hline \multirow{2}{*}{ Age / Week } & \multicolumn{4}{|c|}{ Dietary Treatment (kg / ton) } \\
\cline { 2 - 6 } & $\mathbf{0}$ & $\mathbf{2 . 5}$ & $\mathbf{5}$ & $\mathbf{7 . 5}$ & Standards \\
\hline Blood Cholesterol ( mg /dl) & $267.4 \pm 69.2^{\mathrm{a}}$ & $238.0 \pm 14.1^{\mathrm{a}}$ & $240.0 \pm 10.0^{\mathrm{a}}$ & $236.0 \pm 19.8^{\mathrm{a}}$ & $211.5 \pm 48.9^{\mathrm{a}}$ \\
\hline Blood Albumin (mg / dl) & $6.9 \pm 1.1^{\mathrm{a}}$ & $6.0 \pm 0.5^{\mathrm{a}}$ & $5.7 \pm 1.1^{\mathrm{a}}$ & $6.1 \pm 0.7^{\mathrm{a}}$ & $5.2 \pm 0.5^{\mathrm{b}}$ \\
\hline Blood Triglyceride (mg/dl) & $154.6 \pm 46.6^{\mathrm{a}}$ & $90.4 \pm 14.5^{\mathrm{bc}}$ & $74.0 \pm 16.4^{\mathrm{bc}}$ & $80.3 \pm 3.8^{\mathrm{bc}}$ & $195.7 \pm 27.4^{\mathrm{bd}}$ \\
\hline HDL (mg /dl) & $200.8 \pm 18.4^{\mathrm{a}}$ & $178.3 \pm 4.5^{\mathrm{bc}}$ & $165.5 \pm 10.9^{\mathrm{bc}}$ & $162.1 \pm 10.4^{\mathrm{bd}}$ & $171.0 \pm 5.5^{\mathrm{bcd}}$ \\
\hline LDL (mg /dl) & $34.8 \pm 70.9^{\mathrm{a}}$ & $52.7 \pm 25.7^{\mathrm{a}}$ & $58.6 \pm 16.4^{\mathrm{a}}$ & $57.0 \pm 23.8^{\mathrm{a}}$ & $22.5 \pm 44.6^{\mathrm{a}}$ \\
\hline
\end{tabular}

Data presented in table 5 shows that addition of garlic in diet reduced the blood cholesterol, Albumin, Triglyceride and HDL levels compared with standard levels that reflect the possible mechanism of the lowering action of S-allyl cysteine sulfoxide which is found in Garlic. Prasad et al. [22] reported similar findings were total cholesterol, Triglycerides, and LDL was significantly decreased by adding Garlic to broiler ration.

\section{Conclusions}

Incorporation of garlic powder in broiler diet as feed additive significantly enhanced growth, economic and productive performance of broiler chicks. Physiological measurements (body weight, weight gains, feed intake, feed conversion ratio, carcass weight and internal organs) showed better characteristic of chicken fed with garlic compared with control group under same rearing system. Our investigation showed lower mortality rate, lower susceptibility to diseases and medicament treatment when we used garlic. Meat and blood characteristics showed lower cholesterol, Triglyceride, LDL, HDL levels compared with control group.

It can be concluded that; addition of garlic as growth promoter end in reducing the costs of production through improve feed conversion ratio, weight gain and feeding

efficiency of treated groups compared with untreated groups. The economical evaluation of the experimental diets indicated that, the diet with garlic powder showed higher profitability as compared to the control group. Garlic can be effectively used to replace the antibiotic growth promoter in poultry feed.

\section{Acknowledgements}

Authors are grateful to the Department of Animal Production, Faculty of Agriculture, at Jerash University/ Jordan.

\section{References}

1. Lee MH, Lee HJ, Ryu PD (2001) Public Health Risks: Chemical and Antibiotic Residues Review. Asian-Australian Journal of Animal Science 14: 402-413.

2. Kostadinovic LJ (2013) Herbs and animal health. Monograph University of Novi Sad, Institute for Food Technology, Novi Sad, Serbia 1: 1- 86.

3. Qureshi AA, Abuirmeileh N, Din ZZ, Elson CE, Burger WC (1983) Inhibition of cholesterol and fatty acid biosynthesis in liver enzymes and chicken hepatocytes by polar fractions of garlic lipids 18: 343-348.

4. Cavallito CJ, Buck JS, Suter CM (1994) Allicin, the antibacterial principle of Allium sativum. Determination of the chemical composition, Journal of the American Chemical Society 60: 1952-1958.

5. Iji PA, A Saki, DR Tivey (2001) Body and intestinal growth of broiler chicks on a commercial starter diet. Intestinal weight and mucosal development, British Poultry Science 42: 505-513. 
6. Abouelfetouh AY, Moussa NK (2012) Enhancement of antimicrobial activity of four classes of antibiotics combined with garlic. Asian Journal of Plant Sciences 11: 148-152.

7. Singh MP, Panda H (2005) Medicinal herbs with their formulations, Volume 1-Allium Sativum, Daya Publishing House, Delhi: 110035.

8. Sivam GP (2001) Protection against Helicobacter pylori and other bacterial infections by garlic. J Nutr 131: 1106S-1108S

9. Konjufca VH, Pesti GM, Bakalli RI (1997) Modulation of cholesterol levels in broiler meat by dietary garlic and chopper. Poultry Science 76: 1264-1271.

10. Weber ND, Anderson DO, North JA, Murray BK, Lawson LD (1992) In vitro virucidal effects Allium Sativum (garlic) extract and components. Planta Med 58: 417-423.

11. Ankri S, Mirelman D (1999) Antimicrobial properties of allicin from garlic. Microbes infect 2: 125-129.

12. Demir E, Kiline K, Yildirim Y (2005) Use of antibiotic growth promoter and two herbal natural feed additives with and without exogenous enzymes in wheat base broiler diets. South Africa anim Sci 35: 61-72.

13. Amagase H, Milner JA (1993) Impact of various sources of garlic and their constituents on 7, 12-dimethylbenz (a) anthracene binding to mammary cell DNA. Carcinogenesis 14: 1627-1631.

14. Tsao SM, Yin MC (2001) In vitro activity of garlic oil and four diallyl sulfides against antibiotic resistant Pseudomonas aeruginosa and Klebsiellapneumoniae, Antimicrob. Chemother 47: 665-670.
15. Elagib HAA, Elamin KM El Amin, HEE Malik (2013) Journal of Animal Science Advance 2: 58 - 64

16. Onu PN (2010) Evaluation of two herbal spices as feed additives for finisher broilers, Biotechnology in Animal Husbandry 26: 383 - 392.

17. Tollba AAH, MSH Hassan (2003) Using some natural additives to improve physiological and productive performance of broiler chicks under high temperature conditions, Black cumin (Niglla sativa) or Garlic (Allium sativum).Poultry Science 23: 327-340.

18. Onibi GE, E Oluwatoyin, A Adebisi, N Fajemisin, Ayode Adetun (2009) Response of broiler chickens in terms of performance and meat quality to garlic (Allium sativum) supplementation, African Journal of Agricultural Researc 5:511 - 517.

19. National Research Council (NRC, 1994).

20. Safi E., Mohamed KA, Mukhtar MA (2014) Effect of using Garlic powder as natural feed additive on performance and carcass quality of Broiler chicks.Assiut Vet Med J 2014 60: 141: 45-53.

21. Racesi M, Hoseini Aliabad SA, Roofchaee A, Shahneh A, Pirali S (2010) Effect of Periodically Use of Garlic (Allium sativum) Powder on Performance and Carcass Characteristics in Broiler Chickens. World Academy of Science, Engineering and Technology 68: 1213-1219.

22. Prasad R, Rose MK, Vermani M, Garg SL, Puri JP (2009) Lipid profile of chicken (Gallus Domesticus) in response to dietary supplementation of garlic (Allium Sativum). International Journal of Poultry Science 8: 270-276.

\section{Your next submission with Juniper Publishers will reach you the below assets}

- Quality Editorial service

- Swift Peer Review

- Reprints availability

- E-prints Service

- Manuscript Podcast for convenient understanding

- Global attainment for your research

- Manuscript accessibility in different formats

( Pdf, E-pub, Full Text, Audio)

- Unceasing customer service

Track the below URL for one-step submission https://juniperpublishers.com/online-submission.php 